УДК $532.5+523.2$

\title{
ПРО ТЕМПЕРАТУРНІ ПОЛЯ І УМОВИ КОНДЕНСАЦІЇ ГАЗІВ ТУМАННОСТЕЙ У ПЛАНЕТАРНОМУ ВИХОРІ
}

\author{
Л. В. Ключинська* ${ }^{*}$ В. І. Перехрест** \\ * Севастопольсъкий інститут банківсъкої справи, \\ 99057, Севастополь, E-mail: klyuch.luda.1983@mail.ru \\ ** Дніпропетровсъкий національний університет ім. Олеся Гончара, \\ 49050, Дніпропетровсък, E-mail: prokhrest@i.ua
}

Новий точний розв'язок сферично-осесиметричних рівнянь Ейлера, названий планетарним вихором, застосовано до проблеми утворення в планетарних туманностях зародків планет завдяки конденсації газів у зонах вихрових збурень - кільцях планетарного вихору. Показано, що вихрові збурення спричиняють перепади тиску та температури, за яких гази туманностей конденсуються, утворюючи планетозималі - зародки планет.

Ключові слова:вихрова течія, космічна туманність, температурне поле, конденсація газів.

\section{1. Вступ}

В астрономічній науці теорія утворення зірок і планет у газопилових туманностях є найменш розроблена і зіставна з експериментальними даними. Основний підхід, який домінуе й до сьогодні - це випадкові стохастичні збурення фізичних полів туманності, які спричиняють певну нестабільність їі однорідного стану (ротаційну, турбулентну, термо-, гідро-, магнітодинамічну тощо), що зрештою призводить до конденсації газів та утворення зародків скупчення речовини у так звані планетозималі [6,7]. За логікою такого підходу випадкові у просторі й часі процеси привели б і до випадкових і не зіставних законів розподілу планетних відстаней у Сонячній та інших екзопланетних системах. Однак експериментальні дані [19] переконливо говорять про єдину закономірність законів розподілу планетних відстаней у всіх зіркових системах: із збільшенням номерів планет взаємні відстані між ними збільшуються.

Численні теоретичні дослідження багатьох астрофізиків XX століття $[5,7]$ та відповідні оцінки за реальних параметрів туманностей не дали виразних ефектів нестабільності, фрагментації та утворення зародків формування планет [7]. Найбільш значущим результатом цих досліджень є теорія «довжини і маси» Джинса та відповідний критерій Джинса [5], який визначає критичну довжину хвильового збурення полів туманності, з перевищенням якої настає

(с) Л. В. Ключинська, В. І. Перехрест, 2014 
іï нестабільність і фрагментація, - цим критерієм астрофізики ефективно послуговуються і сьогодні $[13,14]$.

Для подолання вказаних негативних результатів у останні десятиліття інтенсивно розвивались технології числового інтегрування гідродинамічних рівнянь Нав'є-Стокса, ускладнених наявністю термо- та магнітодинамічних полів [12-15]. У математичну модель вносили певні початкові чи постійно діючі нерівномірності - збурення полів густини чи тиску, і у деяких випадках отримували нестабільні вихрові форми, якісно схожі на реальні космічні структури. На сьогодні на цьому шляху реальних результатів не отримано, про що свідчать такі висновки провідних астрофізиків: «Хоча було досліджено різні правдоподібні ідеї, загальної подібності теорії та спостережень не було встановлено» [13].

Сучасний значний прогрес експериментальної астрономії, пов'язаний зі спостереженнями з сучасних потужних телескопічних систем (Hubble, Spitzer, Subaru, VLT, Kepler etc.) на землі й у космосі, поставив низку нових проблем і змусив суттєво переглянути деякі застарілі концепції та вирішувати нові й нові задачі [12]. Зокрема, астрофізики дійшли висновку про необхідність перегляду термінів формування зірок та їх планетних систем, - вони мають бути суттєво зменшені $[16,18]$. Відповідно з'явилися дослідження та статті з лейтмотивом «rapid» - швидкий $[17,18]$.

Інший висновок експериментальної астрономії зводиться до твердження, що планети формувалися не у тих зонах, де вони знаходяться зараз, тобто мова йде про значну міграцію планет $[12,14,15]$.

Більшість з указаних проблемних питань вирішуе створена за останні 5 років теорія планетарного вихору [1-3], яка по-суті доводить правильність вихрової гіпотези К. Вайцзекера [4] про створення Сонячної системи потужним просторовим вихором, який мав стільки вихрових зон-кілець, скільки є великих планет у системі. Хоча ідея К.Вайцзекера через відсутність реальних результатів-розв'язків на той час була відкинута, провідні астрофізики фактично зараз до неї повертаються, досліджуючи гідродинамічні рівняння, які за чисельної реалізації часто породжують певні вихрові структури $[13,18]$.

\section{2. Планетарний вихор і його характеристики}

Наше дослідження температурних полів у вихорі грунтується на точному розв'язку сферично-осесиметричних рівнянь Ейлера [8],

$$
\begin{gathered}
V_{r} \frac{\partial V_{r}}{\partial r}+\frac{V_{\theta}}{r} \frac{\partial V_{r}}{\partial \theta}-\frac{1}{r}\left(V_{\phi}^{2}+V_{\theta}^{2}\right)=-\frac{1}{\rho} \frac{\partial p}{\partial r}, \\
V_{r} \frac{\partial V_{\phi}}{\partial r}+\frac{V_{\theta}}{r} \frac{\partial V_{\phi}}{\partial \theta}+\frac{1}{r}\left(V_{r}-V_{\theta} \operatorname{ctg} \theta\right)=0, \\
V_{r} \frac{\partial V_{\theta}}{\partial r}+\frac{V_{\theta}}{r} \frac{\partial V_{\theta}}{\partial \theta}+\frac{1}{r}\left(V_{r} V_{\theta}-V_{\phi}^{2} \operatorname{ctg} \theta\right)=-\frac{1}{\rho r} \frac{\partial p}{\partial \theta}
\end{gathered}
$$


та рівняння нерозривності

$$
\frac{\partial V_{r}}{\partial r}+\frac{1}{r} \frac{\partial V_{\theta}}{\partial \theta}+\frac{2}{r} V_{r}+\frac{1}{r} V_{\theta} \operatorname{ctg} \theta=0,
$$

де $(r, \theta, \phi)$ - сферичні координати; $V_{r}, V_{\theta}, V_{\phi}$ - компоненти вектора швидкості в цих координатах; $p, \rho$ - тиск і густина нестисливого середовища в області течії.

Після введення функції течії $\Psi(r, \theta)$ залежностями [9]

$$
V_{r}=-\left(r^{2} \sin \theta\right)^{-1} \frac{\partial \Psi}{\partial \theta}, \quad V_{\theta}=(r \sin \theta)^{-1} \frac{\partial \Psi}{\partial r}, \quad V_{\phi}=\frac{\tilde{N}_{0} \Psi}{r \sin \theta}
$$

подаємо її у відокремлених змінних

$$
\Psi=\Phi(r) \Theta(\theta)
$$

з вибором $\Theta=\sin ^{2} \theta$, як це покладалось у більшості досліджень течій цього класу [8-10], а функцію тиску шукаємо у вигляді відрізку ряду Фур'є за кутом $\theta$

$$
p=p_{0}+\frac{\rho}{2}\left(f_{0}(r)+f(r) \cos 2 \theta\right)
$$

де $f_{0}(r), f(r)$ - нові невідомі функції; $p_{0}$ - тиск у точці спокою.

Ці підстановки дають можливість відокремити змінні й отримати для визначальної функції $\Phi(r)$ лінійне диференціальне рівняння 3-го порядку, яке інтегрується аналітично у сферичних функціях Бесселя [1], подібно як у роботах $[10,11]$. Відтак отримуємо розв'язок

$$
\Psi=\left[C_{1} y^{2}+C_{2}\left(\cos y-\frac{\sin y}{y}\right)+C_{3}\left(\sin y+\frac{\cos y}{y}\right)\right] \sin ^{2} \theta,
$$

де $y=C_{0} r$ - безрозмірна радіальна координата; $C_{1}, C_{2}, C_{3}$ - довільні сталі.

Суттєвою перевагою нашого розв'язку $(2.6) \in$ його загальний метод побудови, на відміну від Н.В. Салтанова [10] і А.Г. Ярміцького [11] які слідом за Хіллом [9] застосовують дещо штучну схему спряження на сфері функцій течії поступально-гвинтового руху та розв'язків рівняння 2-го порядку з гіпотетичною функцією енергії. Відповідно розв'язок (2.6) має 3 довільні сталі $C_{1}$, $C_{2}, C_{3}$ та параметр обертання $C_{0}$, варіювання яких спричиняе велике різноманіття вихрових структур (табл. 1 ).

Таблиця 1. Вихрові структури $(n, m)$ залежно від параметра $\alpha$

\begin{tabular}{|c|c|c|}
\hline Інтервали $\alpha$ & $\mathrm{n}$ & $\mathrm{m}$ \\
\hline $0,01186812676<\alpha<1 / 3$ & 1 & $0-6$ \\
\hline$-0,02872363139<\alpha<-0,006519887466$ & 2 & $2-11$ \\
\hline $0,00412853209<\alpha<0,01186812676$ & 3 & $5-18$ \\
\hline$-0,006519887466<\alpha<-0,00285071083$ & 4 & $10-26$ \\
\hline
\end{tabular}


Ці структури можуть зовсім не мати непроникних сфер або ж мати їх $1,2,3, \ldots$ Далі розглянемо неперервний варіант розв'язку (2.6) за $C_{3}=0$, який містить 2 константи $C_{2}$ і $\alpha=C_{1} / C_{2}$. Параметр $\alpha$, зрештою, можна виразити через поступальну швидкість простору $V_{\infty}$ і параметри $C_{0}, C_{2}$ таким чином:

$$
\alpha=-V_{\infty} / 2 C_{0}^{2} C_{2}
$$

- він і визначає структури $(n, m)$ вихорів та умови їх біфуркації (табл. 1$)$.

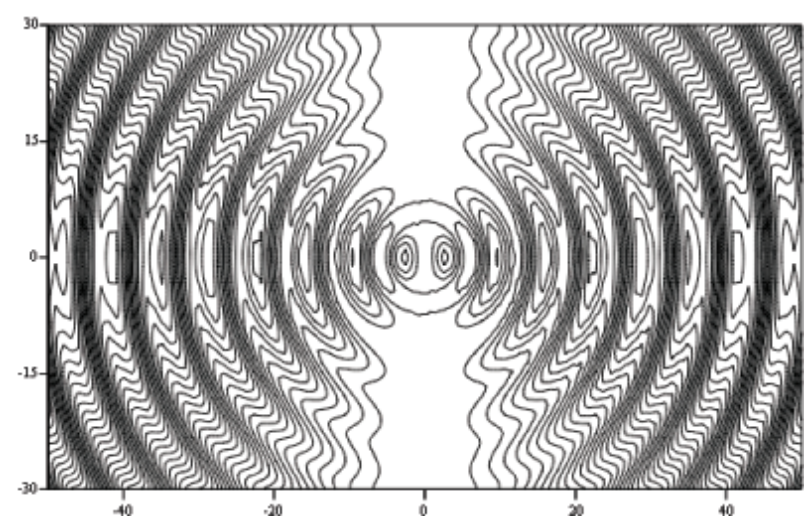

Рис. 1. Загальний вигляд планетарного вихору структури $(2,11)-$ меридіональний переріз

Розв'язок (2.6) описує складну систему тороїдних вихрових кілець, внутрішня частина $n$ яких лежить у замкнутих непроникних сферах, а зовнішні $m$ кілець виокремлюються петлями сепаратрис і обертаються у один бік на зразок планетарних систем зірок (рис. 1, 2).

На рис. 1 зображено планетарний вихор структури $(2,11)$, якому відповідає параметр $\alpha=-0,00655$ і яким ми у попередніх роботах моделювали первинний вихор, що породив Сонячну систему; геометрію зовнішнього вихрового кільця відтворено на рис. 2, геометричні ж параметри усіх кілець цього вихор наведено в табл. 2.

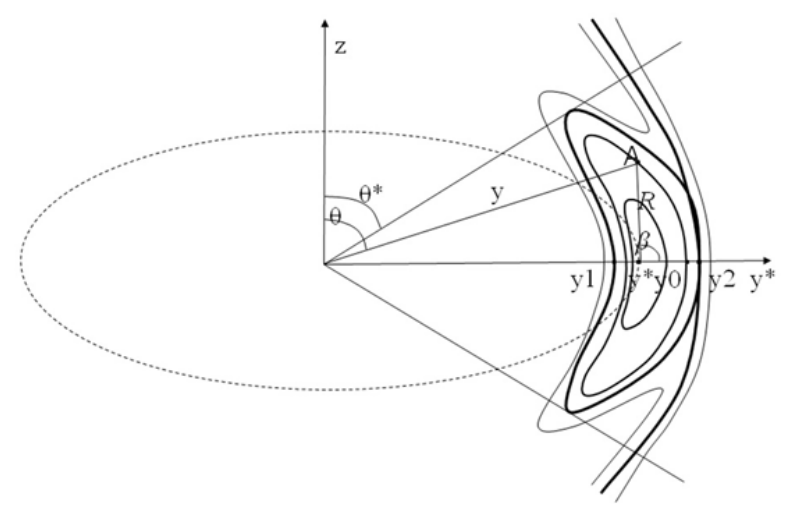

Рис. 2. Геометричні параметри зовнішнього вихрового кільця 
Питання про утворення і природу центрального вихрового диполя, що породжує вихор, тут не порушується - він є стаціонарний точний розв'язок нелінійної системи вихідних рівнянь (2.1), що описує так званий «планетарний вихор» [2].

Таблиця 2. Геометричні параметри кілець вихору структури $(2,11)$

\begin{tabular}{|c|c|c|c|c|}
\hline № кільця & $y_{1}$ & $y^{*}$ & $y_{2}$ & $\theta^{*}$ рад. \\
\hline 1-Сфера & 0 & 2,790261 & 4,638225 & 0 \\
\hline 2-Сфера & 4,638225 & 6,034193 & 7,359705 & 0 \\
\hline $3(1)$ & 7,364163 & 9,442798 & 12,322191 & 0,053788 \\
\hline $4(2)$ & 14,054792 & 15,854359 & 18,549720 & 0,773685 \\
\hline $5(3)$ & 20,651323 & 22,242096 & 24,761679 & 1,025749 \\
\hline 6 (4) & 27,209576 & 28,623985 & 30,965688 & 1,176713 \\
\hline $7(5)$ & 33,749232 & 35,005535 & 37,163518 & 1,278034 \\
\hline $8(6)$ & 40,281229 & 41,389783 & 43,355026 & 1,351129 \\
\hline $9(7)$ & 46,813972 & 47,779428 & 49,538901 & 1,406816 \\
\hline $10(8)$ & 53,356269 & 54,177900 & 55,712465 & 1,451239 \\
\hline $11(9)$ & 59,92070 & 60,590865 & 61,870496 & 1,488292 \\
\hline $12(10)$ & 66,532530 & 67,030608 & 68,000987 & 1,520926 \\
\hline $13(11)$ & 73,283037 & 73,542814 & 74,058441 & 1,552969 \\
\hline
\end{tabular}

Указаний вихровий диполь та породжена ним низка кілець вихрової течії $€$ збуренням первинного гвинтового руху простору, який до того перебував у стані термодинамічної рівноваги з фізичними параметрами $\left\{p_{\infty}, \rho_{\infty}, V_{\infty}, T_{\infty}\right\}$, які зберігаються у збуреній течії за $\theta=0, r \rightarrow \infty$.

\section{3. Диференціальне рівняння енергетичного балансу та інтеграл енергіï}

Далі виходимо з припущення, що матеріал туманностей є ідеальним газом 3 адіабатичним законом для термодинамічних процесів та рівноважними параметрами $\rho_{\infty}=10^{-12} 2 /$ см $^{3}, T_{\infty}=100 K, \gamma=c_{p} / c_{v}=1.67$. За сучасними оцінками астрофізиків, складовими протопланетних туманностей є: $85-90 \%$ водню, 10 - 15\% гелію та до 1\% атомів легких металів [6].

За даних припущень покладемо в основу диференціальне рівняння енергетичного балансу [8]

$$
\rho \frac{d}{d t}\left(U+\frac{V^{2}}{2}\right)=\rho F \cdot V-\operatorname{div}(p V),
$$

де $U=c_{v} T$-внутрішня енергія; $\rho, p, T$ - густина, тиск і температура середовища; $V\left(V_{t}, V_{\theta}, V_{\phi}\right)$ - вектор швидкості; $F$ - вектор зовнішньої масової сили; $c_{v}$ i $c_{p}$ - теплоємності середовища за сталих об'єму та тиску відповідно. 
Застосовуючи закон Клапейрона $p=\rho R T$ та вводячи ентальпію $h=c_{p} T$ рівняння (3.1) зводимо до вигляду

$$
\rho \frac{d}{d t}\left(h+\frac{V^{2}}{2}-\frac{p}{\rho}\right)=\rho F \cdot V-\operatorname{div}(p V),
$$

а подальше застосування рівнянь руху й нерозривності та умови стаціонарності полів $\partial / \partial t()=0$ остаточно приводить до рівняння [8]

$$
V \cdot \operatorname{grad}\left(h+\frac{V^{2}}{2}+\Pi\right)=0,
$$

звідки випливає, що вздовж ліній течії $L$ величина

$$
\left(c_{p} T+\frac{V^{2}}{2}+\Pi\right)_{L}=\text { const } \equiv E_{L},
$$

де П - потенціал зовнішньої сили.

\section{4. Температурні поля в планетарному вихорі}

Вихрова течія планетарного вихору виникає внаслідок збурення гвинтового руху простору: поступального руху зі швидкістю $V_{\infty}$ та твердотільного обертання з кутовою швидкістю $\omega_{\infty}=-\left(C_{0} V_{\infty}\right) / 2$. Відповідне незбурене поле швидкостей має вигляд

$$
\begin{aligned}
& \tilde{V}_{r}=-V_{\infty} \cos \theta \\
& \tilde{V}_{\theta}=V_{\infty} \sin \theta \\
& \tilde{V}_{\phi}=\omega_{\infty} r \sin \theta=-\frac{V_{\infty}}{2} y \sin \theta .
\end{aligned}
$$

Повне поле швидкостей у планетарному вихорі за (2.3) і (2.6) має такі вирази:

$$
\begin{aligned}
V_{r} & =-2 B \frac{\Phi(y)}{y^{2}} \cos t \theta, \\
V_{\theta} & =B \frac{\Phi^{\prime}(y)}{y} \sin \theta, \\
V_{\phi} & =B \frac{\Phi(y)}{y} \sin \theta,
\end{aligned}
$$

де $B=C_{2} C_{0}^{2}$ - параметр із розмірністю швидкості; $C_{2}$ - інтенсивність центрального вихрового диполя. Функції $\Phi$ та $\Phi^{\prime}$ мають подання

$$
\Phi(y)=y^{2}(\alpha+u(y)), \quad \Phi^{\prime}(y)=y\left(2 \alpha-u_{s}(y)\right),
$$

де введено функції-збурення від центрального диполя

$$
u=\frac{1}{y^{2}}\left(\cos y-\frac{\sin y}{y}\right), \quad u_{s}=\frac{\sin y}{y}+u(y)
$$


3 властивостями

$$
\begin{array}{cc}
u(0)=-1 / 3, & \lim _{y \rightarrow \infty} u(y)=0, \\
u_{s}(0)=2 / 3, & \lim _{y \rightarrow \infty} u_{s}(y)=0 .
\end{array}
$$

Враховуючи, що між параметрами задачі має місце співвідношення (2.7) або

$$
\alpha=-V_{\infty} / 2 B \quad \text { або } \quad V_{\infty}=-2 B \alpha, \quad \omega_{\infty} / V_{\infty}=-C_{0} / 2,
$$

повне поле швидкостей (4.2) можна представити як суму незбуреного поля (4.1) та збурень, що містять функції диполя $u$ та $u_{s}$ :

$$
V_{r}=\left(V_{\infty}-2 B u\right) \cos \theta, \quad V_{\theta}=-\left(V_{\infty}+B u_{s}\right) \sin \theta, \quad V_{\phi}=\tilde{V}_{\phi}+B u y \sin \theta .
$$

Підрахуємо тепер квадрат швидкості $V^{2}$, виділивши в ньому квадрати незбурених швидкостей (4.1):

$$
\begin{array}{r}
\frac{V^{2}}{2}=\frac{1}{2}\left(\tilde{V}_{r}^{2}+\tilde{V}_{\theta}^{2}+\tilde{V}_{\phi}^{2}\right)+\left(-2 B V_{\infty} u+2 B^{2} u^{2}\right) \cos ^{2} \theta+ \\
+\left(B V_{\infty} u_{s}+\frac{1}{2} B^{2} u_{s}^{2}\right) \sin ^{2} \theta+B \tilde{V}_{\infty} u y \sin \theta+\frac{1}{2} B^{2} y^{2} u^{2} \sin ^{2} \theta
\end{array}
$$

3 урахуванням (4.1) розглянемо вираз інтеграла (3.3) вздовж осі $O z$, яка, очевидно, є лінією течії (рис. 1). На ній $\theta=0, V_{\phi}=0, V(\infty)=V_{\infty} .3(4.1)$ в будь-якій точці осі маємо

$$
V^{2} / 2=V_{\infty}^{2} / 2-2 B V_{\infty} u+2 B^{2} u^{2}
$$

Визначивши константу в $(3.3)$ з умови за $y \rightarrow \infty$ через $V_{\infty}, T_{\infty}$, вздовж осі Oz маємо рівняння

$$
c_{p} T+V_{\infty}^{2} / 2-2 B V_{\infty} u+2 B^{2} u^{2}=c_{p} T_{\infty}+V_{\infty}^{2} / 2
$$

яке після спрощення зведемо до вигляду

$$
\tau_{0} \equiv\left(\frac{T}{T_{\infty}}\right)_{\theta=0}=1-k_{T}\left(\frac{u^{2}}{\alpha^{2}}+\frac{2 u}{\alpha}\right)=1-k_{T}\left(\frac{(u+\alpha)^{2}}{\alpha^{2}}-1\right)
$$

де $k_{T}=V_{\infty}^{2} /\left(2 c_{p} T_{\infty}\right)$ - безрозмірний параметр, що визначає співвідношення основних параметрів задачі.

3 (4.9) визначимо температурний параметр $\tau=T / T_{\infty}$ у точці перетину вертикальної осі з першою ззовні сферою радіусом $y=y_{1}$, яка теж $є$ лінією течії і на якій з умови $V_{r}=0$ з огляду на (4.2) і (4.3) $u\left(y_{1}\right)+\alpha=0$. Отже, в точці $\left(y_{1}, 0\right)$ маємо

$$
\tau_{1}=1+k_{T} \quad \text { i } \quad T_{1}=\left(1+k_{T}\right) T_{\infty}
$$

Звідси $T_{1}>T_{\infty}$, і в околі вертикальної осі вихору конденсація не виникає, про що свідчить більшість знімків таких протозіркових туманностей. 
Тепер застосуємо інтеграл (2.3) до лінії течії - кола $y=y_{1}, 0 \leq \theta \leq \pi / 2$. На ній у точці $\left(y_{1}, 0\right) V=0$ і константа $E_{L}=c_{p} T_{1}$, тому вздовж цієї лінії

$$
\left(c_{p} T+\frac{V^{2}}{2}\right)_{y_{1}}=c_{p} T_{1}=c_{p} T_{\infty}+\frac{V_{\infty}^{2}}{2}
$$

а кінетична енергія дається виразом (4.1) за $\theta=\pi / 2$.

Перейдемо вздовж ціеі лінії в горизонтальну площину $\theta=\pi / 2$ і перепишемо вираз (4.5) з урахуванням (4.8) так:

$$
c_{p} T+\frac{V_{\infty}^{2}}{2}\left[1+\left(\frac{u_{s}^{2}}{4 \alpha^{2}}-\frac{u_{s}}{\alpha}\right)+y^{2}\left(\frac{(u+\alpha)^{2}}{4 \alpha^{2}}-\frac{1}{4}\right)\right]+\frac{V_{\infty}^{2} y^{2}}{2 \cdot 4}=c_{p} T_{\infty}+\frac{V_{\infty}^{2}}{2}
$$

або після скорочення і застосування умови $u\left(y_{1}\right)+\alpha=0$

$$
T_{2}=T_{\infty}-\frac{V_{\infty}^{2}}{2 c_{p}}\left[\frac{u_{s}^{2}}{4 \alpha^{2}}-\frac{u_{s}}{\alpha}\right]_{y=y_{1}}, \quad \tau_{2}=1-k_{T}\left[\frac{u_{s}^{2}}{4 \alpha^{2}}-\frac{u_{s}}{\alpha}\right]_{y=y_{1}}
$$

Очевидно, що на різних лініях течії, які перетинають горизонтальну вісь $\theta=$ $\pi / 2$, повна енергія (3.3) буде неперервною функцією змінних $(T, y)$, тобто

$$
\begin{array}{r}
E_{L}(T, y)=c_{p} T+\frac{V_{\infty}^{2}}{2}\left[1+\left(\frac{u_{s}^{2}}{4 \alpha^{2}}-\frac{u_{s}}{\alpha}\right)+\right. \\
\left.y^{2}\left(\frac{(u+\alpha)^{2}}{4 \alpha^{2}}-\frac{1}{4}\right)\right] \\
+\frac{\tilde{V}_{\phi}^{2}}{2} \quad y_{1} \leq y \leq \infty .
\end{array}
$$

При цьому відомі ї̈ значення у точках $y=y_{1}(4.12)$ та за $y \rightarrow \infty$, де $V=V_{\infty}$, $T=T_{\infty}$.

Уздовж незамкнутих ліній течії, які по вертикалі прямують до $z \rightarrow \infty$, вираз (4.13) фіксується у точці у і зберігається вздовж кожної такої лінії, маючи у нескінченно віддаленій горизонтальній площині значення

$$
E_{L}(\infty, y)=c_{p} T_{\infty}+\frac{V_{\infty}^{2}}{2}+\frac{\tilde{V}_{\phi}^{2}}{2} \quad y_{1} \leq y \leq \infty
$$

Прирівнюючи вирази (4.13) i (4.14), будуємо функцію $T(y)$ на горизонтальній осі з точністю до адитивної константи:

$$
T=T_{\infty}-k_{T} T_{\infty}\left[\left(\frac{u_{s}^{2}}{4 \alpha^{2}}-\frac{u_{s}}{\alpha}\right)+y^{2}\left(\frac{(u+\alpha)^{2}}{4 \alpha^{2}}-\frac{1}{4}\right)\right]+T_{c} .
$$

Останню визначимо з умови, щоб у точці перетину кола $y=y_{1} 3$ горизонтальною віссю температура $T$ була неперервною. Відтак отримуємо

$$
T_{c}=-k_{T} \frac{y_{1}^{2}}{4} T_{\infty}
$$


Формулі (4.15) з допомогою (4.6) можна надати такого вигляду:

$$
\tau(y)=1-k_{B}\left[\left(u_{s}^{2}-4 \alpha u_{s}\right)+\alpha^{2} y_{1}^{2}+y^{2}\left(u^{2}+2 \alpha u\right)\right],
$$

де $k_{B}=B^{2} / 2 c_{p} T_{\infty}$. Зображення (4.17) зручне тим, що можна варіювати швидкість збурення $B$ та здійснювати граничний перехід $B \rightarrow 0$ відповідно $\tau \rightarrow 1, T \rightarrow T_{\infty}$.

Враховуючи асимптотичні властивості функцій $u(y)$ та $u_{s}(y)$ із (4.4) та (4.5) за умови $y \rightarrow \infty$, з (4.17) отримаємо асимптотичну формулу

$$
\tau_{\infty} \approx 1-k_{B}\left(2 \alpha \cos y+\alpha^{2} y_{1}^{2}\right)
$$

яку підтверджує графік залежності (4.17) на рис. 3. На рис. 5, а видно, як в туманності Egg Nebula завдяки періодичним збуренням простору виникають періодичні кільцеві зони конденсації, що повністю відповідає нашій теорії (рис. 3). Для вибраного числового прикладу з $k_{B}=45$ коливання мають розмах від $20 K$ до $140 K$, якщо $T_{\infty}=100 K$.

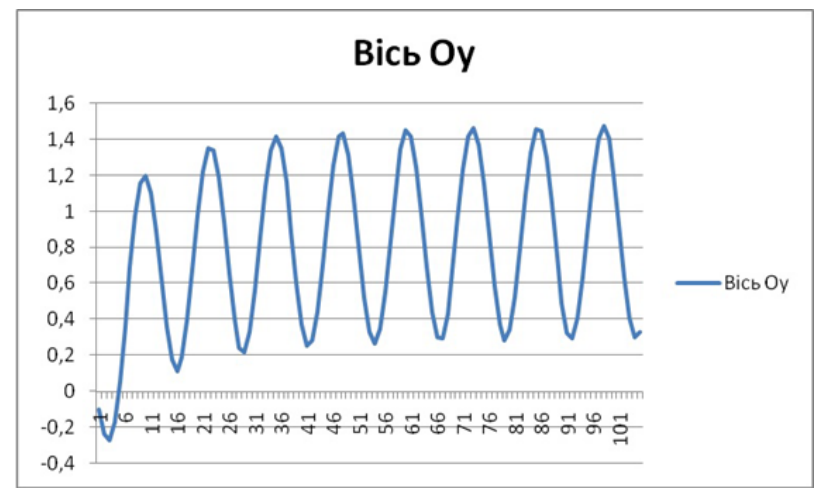

Рис. 3. Температурний коефіцієнт уздовж осі $O y\left(1\right.$ відповідає $\left.T=T_{\infty}\right)$

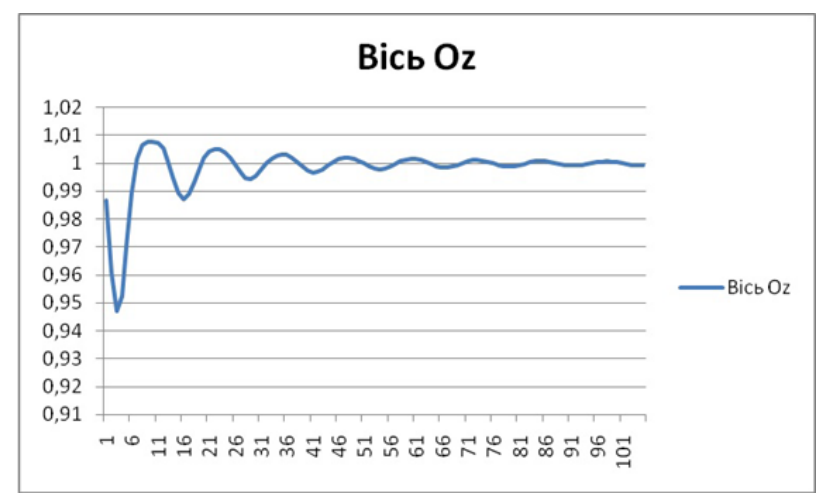

Рис. 4. Температурний коефіцієнт уздовж осі $O z\left(1\right.$ відповідає $\left.T=T_{\infty}\right)$

Графік зміни температури вздовж осі вихору $O z$ (рис. 4) свідчить, що температурні хвилі збурення, які є значні у зоні перших двох сфер, далі досить швидко зникають, а коливання мають порядок $\pm 1-2 K$. Це означає, 
що вздовж осі вихору конденсація практично не виникає, що й демонструють численні знімки планетарних туманностей, у яких формується зірка та її планетна система (рис. 5, б).

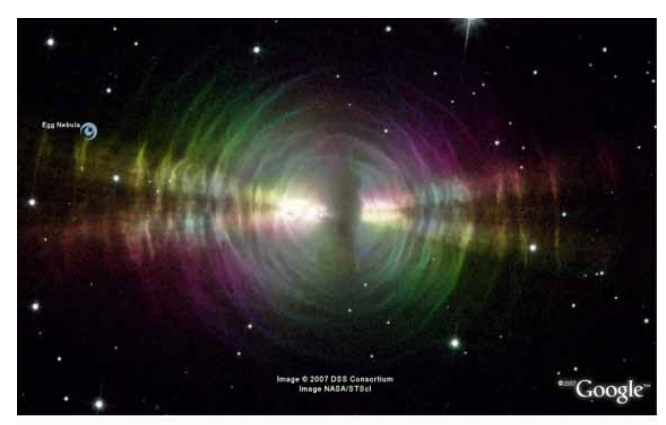

$a$

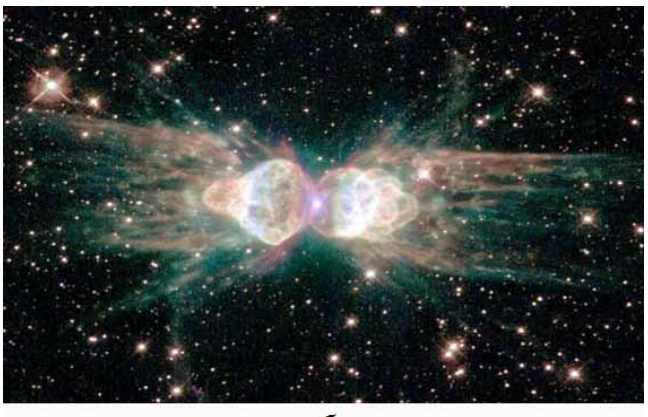

6

Рис. 5. Протозіркові туманності: $a$ - туманність Egg Nebula (фронтальний вигляд); 6 - туманність М-3 (вигляд збоку)

У табл. 3 наведено значення мінімумів температур та точки $y=y_{\min }$, де вони досягаються; паралельно вказано координати $y^{*}$ найближчих до них центрів вихрових кілець вихору $(2,11)$. Порівняння $\min 3$ даними $y_{1}$ та $y^{*}$ (табл. 2) говорить про те, що мінімальні температури мають місце у області вихрових кілець. Це сприяє утворенню на їх центрах зародків планет, оскільки за результатами роботи [20] у разі подальшої еволюції вихору центральні кола перетнуть усі внутрішні тороїди кільця, які, таким чином, будуть намотуватися на них, стикатися і злипатися.

Таблиця 3. Мінімальні температури, їх координати та радіуси центрів кілець у вихорі $(2,11)$

\begin{tabular}{|c|c|c|c|}
\hline № кілець & $T_{\min }$ & $y_{\min }$ & $y^{*}$ \\
\hline 1 & $-0,26940$ & 9 & 9,4428 \\
\hline 2 & 0,111901 & 15,5 & 15,854 \\
\hline 3 & 0,215930 & 22 & 22,242 \\
\hline 4 & 0,234861 & 28 & 28,624 \\
\hline 5 & 0,267108 & 34,5 & 35,006 \\
\hline 6 & 0,279138 & 41 & 41,39 \\
\hline 7 & 0,285947 & 47 & 47,779 \\
\hline 8 & 0,292221 & 53,5 & 54,178 \\
\hline 9 & 0,298558 & 59,5 & 60,59 \\
\hline 10 & 0,304273 & 66 & 67,03 \\
\hline 11 & 0,309321 & 72,5 & 73,543 \\
\hline
\end{tabular}




\section{5. Висновки}

1. Центральний вихровий диполь, здатний породити систему кілець порядку 10, є дуже потужним збуренням квазістаціонарного поля туманності, і в околі його центру, до $y \approx 10$, теоретичні падіння тиску й температур перевищують умови вакууму і тому $е$ фізично неприйнятні. Як уже зазначалось нами $[2,3]$, у даному випадку головними повинні бути інші фізичні чинники й закономірності, пов'язані з ядерними й електромагнітними процесами.

2. У межах зовнішніх вихрових кілець результати термодинамічного аналізу є більш прийнятні. Звертаємо увагу на різну поведінку температурних полів уздовж осі вихору $O z$ та горизонтальної осі $O y$, а саме: уздовж осі вихору $O z$ після різкого падіння в центрі температура швидко стабілізується в околі $1\left(T_{\infty}\right)$, тоді як у площині вихору коливні збурення температури $є$ практично незгасаючими і для вибраного числового варіанта коливаються між $1,4-0,2$ від $T_{\infty}$. За $T_{\infty}=100 K$ ці коливання становлять $20 K-140 K$, і зрозуміло, що у разі таких перепадів водень, гелій та азот конденсуються у кільцевих зонах мінімальних температур. Для них температури кипіння $T_{\mathrm{H} 2}=20,28 K, T_{\mathrm{He}}=4,21 K, T_{\mathrm{N} 2}=77,4 K$.

3. Указані зони конденсації знаходяться в околах центрів вихрових кілець (табл. 2,3), і цей фактор є сприятливий для утворення 3 цих кілець твердих планет на їх центральних колах, рух на яких є стійкий, що було доведено нами раніше [21].

\section{Бібліографічні посилання}

1. Перехрест В. I. Новий розв'язок гідродинамічних рівнянь Ейлера для сферичних вихрових течій / В. І. Перехрест, Р. В. Іванов // Вісник ДНУ. Серія: Механіка. - Д. : Вид-во ДНУ. - 2002. - Вип. 6, т. 1. - С. 60-64.

2. Перехрест B. I. Планетарний вихор та гіпотези Лапласа і Вайцзекера / В. І. Перехрест // Вісник ДНУ. Серія: Механіка. - Д. : Вид-во ДНУ. - 2009. - Вип. 13, т. 2. - C. $113-124$.

3. Перехрест В. I. Закон планетних відстаней у вихровій теорії планетарних систем / В. І. Перехрест // Вісник ДНУ. Серія: Механіка. - Д. : Вид-во ДНУ. - 2011. - Вип. 15, т. 1. - С. 21-33.

4. Weizsăcker C. F. Über die Entstehung des Planetensystems / C. F. Weizsăcker // Z. Astrophys. - 1943. - P. 319-355.

5. Jeans J. H. Astronomy and cosmogony / J. H. Jeans. - Cambridge, 1929. - 320 p.

6. Кононович Э. В. Общий курс астрономии / Э. В. Кононович, В. И. Мороз М. : Эдиториал УРСС, 2004. - 544 c.

7. Сафронов В. C. Эволюция допланетного облака и образование Земли и планет / В. С. Сафронов - М. : Наука, 1969. - 245 с.

8. Лойuянский Л. Г.Механика жидкости и газа / Л. Г. Лойцянский - М. : Дрофа, 2003. $-840 \mathrm{c}$.

9. Милн-Томпсон Теоретическая гидродинамика / Милн-Томпсон. - М. : ИЛ, 1964. $-655 \mathrm{c}$.

10. Салтанов Н. В. Вихрь на сфере во внешнем потенциальном потоке и его связь с вихрем Хилла / Н. В. Салтанов, В. Н. Салтанов// К. : Доповіді НАНУ. 1988. 一 № 9. - C. $70-75$. 
11. Ярмицкий А. Г. Сферические вихреобразования с ядром и оболочкой / А. Г. Ярмицкий // Изв. РАН. Сер. Механика жидкости и газа. - 2001. - № 3. - С. 21-27.

12. Boss A. P. Edited Vince Maunings / A. P. Boss, S. S. Russel // Protostars\&Planets IV, Arizona Press. - 2000. - 378 p.

13. Bodenheimer P. Multiple fragmentataion of protostars / P. Bodenheimer, A. Burkert, R. Klein, A. Boss // Protostars\&Planets IV, Arizona Press. - 2000. - P. 675-701.

14. Wuchterl G. Giant planet formation / G. Wuchterl, T. Guillot, J. Lissauer // Protostars\&Planets IV, Arizona Press, 2000. - P. 1081-1109.

15. Ward W. R. Disk-planet interactions and the formation of planetary systems / W. R. Ward, J. Hahn // Protostars\&Planets IV, Arizona Press. - 2000. - P. 11351155 .

16. Ксанфомалити Л. В. Солнечная система, планетные системы звёзд и теория последовательной аккреции / Л. В. Ксанфомалити // Кинематика и физика небесных тел. - К. : ГАО НАНУ. - 2010. - Т. 26, № 4. - С. 84-106.

17. Mudryk I. R. RAPID: A fast, high resolution, flux-conservative algorithm desined for planet-disk interaction [Electronic resources] / I. R. Mudryk, N. W. Murray // The Journal of New Astronomy. - 2009. - [Cited 2008, 15 Dec.]. - Available from: http://arxiv.org/abs/0812.2938.

18. Boss A. P. Rapid formation of outer giant planets by disk instabiliny / A. P. Boss // Astroph. Journal, 10 December. - 2003. - P. 577-581.

19. The Exoplanet Data Explorer [Electronic resources] - Available from: http: // exoplanets.org/table? datasets=explorer,kepler,other

20. Перехрест B. I. Інваріантні властивості кілець планетарного вихору та їх вплив на еволюцію вихору / В. І. Перехрест, Л. В. Ключинська // Вісник ДНУ. Серія: Моделювання. - Д. : Вид-во ДНУ. - 2013. - Вип. 5, т. 21, № 8. - С. 107-117.

21. Перехрест B. I. Про стійкість і резонанси рухів у торових кільцях планетарного вихору / В. І. Перехрест, М. М. Осипчук, Л. В. Ключинська // Вісник ДНУ. Серія: Моделювання. - Д. : Вид-во ДНУ. - 2013. - Вип. 5, т. 21, № 8. - С. $98-$ 106. 